\section{dr. Konrad}

Elsdon

Univerza

$v$ Nottinghamu

\title{
PROSTOVOLJNE ORGANIZACIJE IN IZOBRAŽEVANJE ODRASLIH
}

\author{
Učenje in osebnostno spreminjanje \\ $\checkmark$ prostovoljnih organizacijah
}

V pričujočem prispevku bom najprej poskušal podati tri širše definicije, ki naj bodo podlaga za nadaljnja razmišljanja:

Izobraževanje odraslih je organizirano in koherentno učenje odraslih (ne glede na vsebino), ki poteka pod vodstvom učitelja; učitelj je lahko ena sama ali več oseb hkrati, ustanova ali kak drug koherenten vir učenja (npr. besedilo, serija radijskih oddaj, itd.).

Izobraževanje odraslih in spremembe niso samo učenje, ki poteka, kot sem že omenil, marveč tudi učenje, ki ni organizirano, ki ni strukturirano, ki spremeni in razvija osebnost, vse tisto, kar odrasli doživijo kot posledico tega, da živijo in so del naravnega okolja, da se povezujejo z drugimi in da so člani družbe.

Prostovoljne organizacije so trajnejše skupine, $v$ katerih se zbirajo moški in ženske po lastni volji iz razlogov, ki niso predvsem ekonomske narave. Vsi tisti torej, ki si prizadevajo za skupne interese, ideale, dejavnosti po lastni izbiri, ki jih tudi sami nadzorujejo.

\section{PROSTOVOLJNE ORGANIZACIJE IMAJO SVOJE ZNAČILNOSTI}

Definicija iz prejšnjega odstavka je dokaj široka in ohlapna. Oprijemljivejša postane, ko jo povežemo s strukturami, tradicijo, zakoni, ki so v različnih državah precej različni. Ko govorim o prostovoljnih organizacijah, imam $\mathrm{v}$ mislih tiste, ki ustrezajo tej široki in ohlapni definiciji. Predvsem morajo biti trajne. Če se tovornjak, naložen s pivom, prevrne na cesti in se možje združijo, da ga spet postavijo pokonci, njihovega prizadevanje še ne moremo opredeliti kot prostovoljno organizacijo. $\mathrm{O}$ cilju svojega prizadevanja se morajo možje dogovoriti, organizirati se morajo, da pridejo do cilja, to drži, vendar njihovo sodelovanje traja le kratek čas. Združijo se, da pomagajo vozniku ohraniti delovno mesto, plačila ne dobijo, čeprav morda dejanju sledi veselo praznovanje. Dejanje je v tem primeru le naključno in nikakor ni prostovoljna organizacija. Po drugi strani pa je gorska reševalna ekipa trajna prostovoljna organizacija. Večina reševalcev ostaja na voljo ponesrečenim, vse dokler jim to dopuščajo telesne moči. Člani se ekipi priključijo prostovoljno, plačila ne dobijo. Svoj prosti čas porabijo za urjenje v vseh potrebnih veščinah planinarjenja, iskanja ponesrečenih in reševanja, prve pomoči, vzpostavljanja radijskih zvez, skratka vsega, kar je potrebno za ukrepanje $\mathrm{v}$ primeru nesreče.

Ta primer ustreza drugemu in tretjemu kriteriju: člani se priključijo ekipi po lastni volji, svoje znanje in pomoč ponujajo brez ekonomskih motivov, še več, organizaciji plačajo letno članarino. V marsičem se razlikujejo od skupin prostovoljcev, ki se priključijo bolnišnici, torej organizaciji, ki ni neodvisna in ima lastne cilje. Ti prostovoljci so pravzaprav neplačani uslužbenci državne organizacije.

Zadnji kriterij, ki sem ga izbral, je lastni interes. Ta lahko obsega vse, od nogometa, zborovskega petja, religije, vrtnarjenja in politike do reje golobov pismonoš: najpomembneje je, da člani prostovoljne organizacije izberejo, kaj bo ta počela, da prevzamejo odgovornost

Vse države se ponašajo z bogastvom svojega skupnostnega Živlienja in prostovolinimi organizacijami, čeprav nekatere močno otezujejo njhov obstoj in razvoj. Tako ne katere zrele demokratične države zahtevajo, da si ljudje pridobijo uradno dovoljenje za ustanovitev prostovoline organizacije. 
za njeno delo in da jo sami nadzorujejo. Bistvene značilnosti takšne organizacije niso velikost, vplivnost, financiranje, storitve ali vsebina delovanja, temveč koncepti članstva, pripadnosti, notranje motivacije in avtonomnosti.

V Veliki Britaniji je približno 1,4 milijona prostovoljnih organizacij vseh vrst, oblik in velikosti, ki združujejo od 20 do 25 odstotkov prebivalstva. V njih je vključenih vsaj 33 milijonov odraslih. Nekateri ne pripadajo nobeni prostovoljni organizaciji, nekateri le eni do dvema, velika večina pa več in mnogi mnogim prostovoljnim organizacijam. Od 33 milijonov vključenih prevzame približno četrtina vsaj nekaj odgovornosti za delovanje organizacij, bodisi s formalno izvolitvijo ali kako drugače. Približno 85 odstotkov prostovoljnih organizacii ima manj kot sto članov, 55 odstotkov manj kot trideset, 85 odstotkov organizacij nima nobenega zaposlenega. Domala $v$ vseh člani upravljajo demokratično na formalne ali neformalne načine. Približno 70 odstotkov je velikih, imajo dobro kadrovsko zasedbo in so zdravstvene ali socialno-varstvene prostovoljne organizacije; okoli 12 odstotkov teh organizacij najverjetneje sodi $\mathrm{k}$ skupinam za samopomoč. 70 do 80 odstotkov vseh prostovoljnih organizacij zadovoljuje osebne interese članov. V povprečju 35 do 40 odstotkov vseh organizacij deluje na področju ljubiteljskega športa in iger; največje prostovoljne skupine se ukvarjajo $\mathrm{z}$ nogometom.

Bržkone drži, da je prostovoljni sektor manj razvit $\mathrm{v}$ državah, kjer je dolgo uspešno vladala diktatura, kratko malo zato, ker so se državljani navadili, da jih organizirajo drugi, »od zgoraj«. V nekdanji Vzhodni Nemčiji so bili mnenja, da je $v$ dveh generacijah pod nacizmom in potem pod komunističnim režimom duh prostovoljstva povsem zvodenel. Ko pa so začeli obujati prostovoljstvo in zasnovali nekaj izjemno zanimivih razvojnih projektov, so kmalu ugotovili, da je v državi ves čas delovalo manjše število neformalnih klubov in združb, da so se tiho in neopazno razvijali in da so zdaj pripravljeni deliti svoje omejene izkušnje demokracije in odgovornosti z različnimi skupnostmi, ki se učijo oziroma znova učijo odgovornosti za lastno usodo (glej Netzwerk Sudost 1998).

Omenil sem že, da večina prostovoljnih orga-

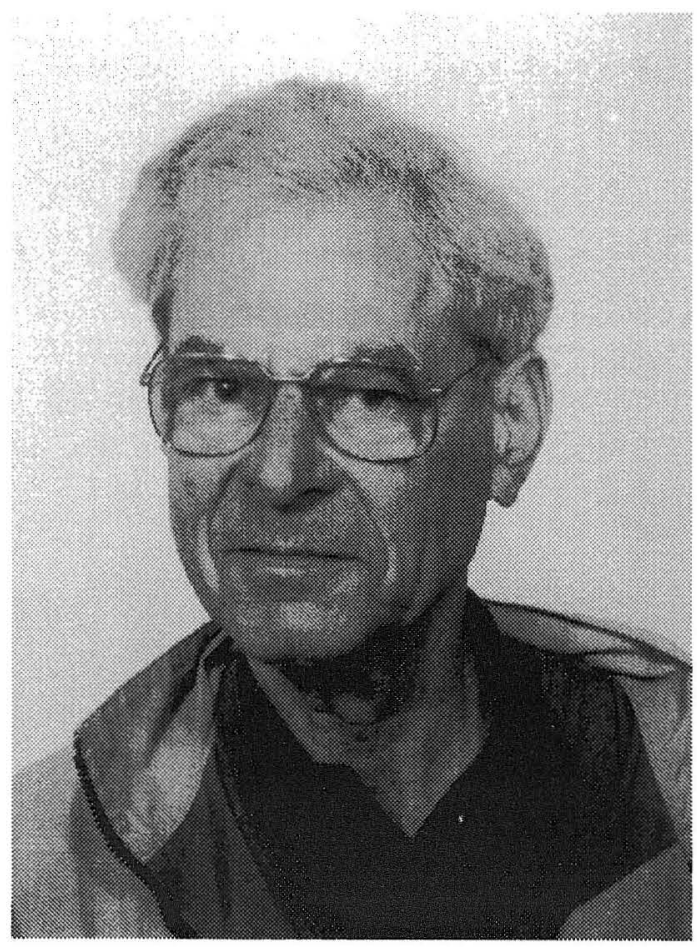

dr. Konrad Elsdon

nizacij temelji na osebnih interesih članov. $\mathrm{Na}$ želji, da bi blesteli na ljubiteljskem nogometnem igrišču, na želji, da bi poslušali predavanja ali odkrivali preteklost, da bi sodelovali $\mathrm{v}$ godalnem kvartetu, igrali tenis, premagali vladajočo stranko ali pomagali starejšim in invalidnim osebam. Takšne želje navedejo ljudi $\mathrm{k}$ temu, da se pridružijo prostovoljnim organizacijam. Večino teh organizacij tako lahko pojmujemo kot specializirane organizacije ali pa, nasprotno, organizacije splošne narave in vsebine, če podpirajo različne interese iste vrste, npr. vse športe ali pa celo vrsto intelektualnih interesov, kot, denimo, to počne čitalniški krožek. Klubi, ki bi zadovoljevali zgolj potrebe po druženju, so res $\mathrm{v}$ manjšini.

Ugotovili smo, da so cilji, ki jih izraža posamezna prostovoljna organizacija, in razlogi za priključitev posameznih članov na začetku soglasni. Ko pa povprašamo posameznike, kakšne ugodnosti jim prinaša članstvo, se razkrije veliko navzkrižje med cilji organizacije in osebnim dobitkom; dobitki so mnogo večji in širši od organizacijskih ciljev. Zaslediti pa je tudi izjeme. V primeru zelo specializiranih organizacij in dejavnosti, kot je, denimo, reja golobov pismonoš, je navzkrižje manjše, čeprav še zmeraj obstaja.

Inkogruenca ali neskladje je izraz, ki ga upo- 
rabljamo v geometriji. Z njim označujemo dejstvo, da se dva lika ne ujemata povsem. Če ju preganemo po diagonali, ki jima je skupna, nastanejo krila, ki spominjajo na metulja. Podobno sliko dobimo, če primerjamo organizacijske cilje in osebni dobitek članov prostovoljne organizacije. V mnogočem se pokrivajo, v mnogočem razhajajo. Vsi člani se razlikujejo med seboj. Koliko se razlikujejo in $\mathrm{v}$ kakšno smer težijo v svojih željah in prizadevanjih, pa je odvisno od slehernega člana posebej.

Zakaj je tako? V prostovoljni organizaciji se zbere skupina ljudi, ki prevzame odgovornost za tisto, kar želi postoriti in doseči. $\mathrm{V}$ vsaki skupini so ljudje povezani med seboj, odgovorni skupaj z drugimi in za druge. To pomeni, da poleg vsebine dejavnosti - intelektualne, telesne ali družbene ali vseh treh po malem - nanje vpliva tudi narava odnosov, ki se rodijo v skupni izkušnji. Izobraževalci odraslih vemo, kaj to pomeni. Vemo, kakšna je razlika med predavanjem in študijsko skupino ali zasebno inštrukcijo.

\section{UČENJE IN SPREMINJANJE ČLANOV}

Dolga leta sem se ukvarjal z učenjem in spreminjanjem $\mathrm{v}$ prostovoljnih organizacijah. $\mathrm{V}$ prvih dveh letih sta me spremljala kolega John Reynolds in Susan Stewart. Večino časa smo posvetili odkrivanju posledic sodelovanja $\mathrm{v}$ prostovoljnih organizacijah za posame-

Nova znanja, novo vedenje in nove spretnosti se razvijejo med skupnim delovanjem. Ljudje se učijo drug od drugega brez formalnih učnih procesov in pogosto ne da bi se prav zavedali tega, kar se dogaja. organizacijami, prostovoljnimi organizacija$\mathrm{mi}$ in državnim ali javnim sektorjem

Naj s tem v zvezi povem le to, da smo v vseh primerih odkrili vsaj nekaj izobraževanja odraslih in veliko učenja in spreminjanja odraslih, pogosto prav presenetljivega spreminjanja. Ker so prostovoljne organizacije zelo neuradne, so učenje in osebnostne spremembe posledica skupnega delovanja članov. Pravzaprav je bilo naše najzanimivejše odkritje to, da se ljudje ne zavedajo, česa vsega se naučijo in kako se spreminjajo. Tega se zavedo šele ob vprašanjih, ki jim jih zastavimo. Ko pa se zavedo, so presenečeni, kaj vse so dosegli, in jim je to spoznanje v oporo pri nadaljnjem učenju.

Ta nezavedni proces osebnega in organizacijskega razvoja je bistvena prvina prostovoljnih organizacij. Učenje odraslih poteka navkljub neformalnosti prostovoljnih organizacij. Seveda nekatere izmed njih, denimo čitalniška društva, obstajajo zato, da širijo izobraževanje odraslih. V športnih klubih je vedno zaslediti mentorstvo. $V$ glasbenih društvih dirigenti vidno poučujejo, enako velja za vodje nekaterih dramskih skupin. Klubi vrtnarjenja in društva za zdravo okolje prirejajo razgovore in predavanja in nekatere prostovoljne organizacije (npr. arheološka društva) zahtevajo sodelovanje v sistematičnih oblikah izobraževanja, še preden se jim posamezniki pridružijo, da bi sodelovali v nekaterih zahtevnejših dejavnostih.

\section{PET VRST UČENJA IN OSEBNOSTNEGA SPREMINJANIA}

Preučevanje izobraževanja odraslih in učenja ter spreminjanja odraslih nam je narekovalo, da 1100 posameznikov, $\mathrm{v}$ študijo vključenih članov prostovoljnih organizacij, razporedimo v kategorije. Odkrili smo pet različnih vrst učenja in spreminjanja.

1. Najprej vsebinsko učenje, se pravi učenje, pridobivanje znanj ali spretnosti, o katerih govorijo organizacijski cilji prostovoljne organizacije. Gre za boljše igranje tenisa, za boljše poznavanje slovenskega jezika, itd. Tam, kjer prostovoljna organizacija sponzorira formalno izobraževanje odraslih, gre predvsem za učenje vsebin ali vsebinsko učenje. 
2. Naslednja kategorija je skupnostno ali socialno učenje in spreminjanje. Naši vprašanci so pogosto omenjali, da je to učenje med najpomembnejšimi. Mnogi so povedali, da so v prostovoljni organizaciji postali samozavestnejši, da so bolje vzpostavljali odnose z drugimi, sodelovali z drugimi in prevzemali odgovornost v skupini. Bolj so zaupali lastnemu mnenju in laže so spregovorili ali se postavili za svoje mnenje $\mathrm{v}$ diskusiji.

3. Tretja kategorija je poklicno učenje. To je bilo omenjeno manj pogosto. Razumljivo, saj je razmeroma malo prostovoljnih organizacij poklicnih združenj (npr. Britansko medicinsko združenje, ki je namenjeno le zdravnikom). Takih združenj nismo vključili v preučevani vzorec. Ljudje se napogosteje priključijo društvu v želji po dejavnostih za prosti čas, ki so v nasprotju s tistim, kar počno poklicno. In vendar je približno 58 odstotkov vprašanih odgovorilo, da so izkušnje, ki so si jih pridobili $\mathrm{v}$ prostovoljnih organizacijah, dobro vplivale na njihovo poklicno delo. Največkrat tako, da so se tam naučili splošnih spretnosti in ravnanja, ki so jih lahko neposredno uporabili pri delu. Med temi so predvsem upravne, politične in organizacijske spretnosti, ki so se jih naučili, ko so prevzeli odgovornost znotraj prostovoljne organizacije. Te so kasneje prenesli $\mathrm{v}$ industrijo ali lokalno upravo. Druge spretnosti so bile bolj specifične, npr. pisanje, ki so se ga naučili v prostovoljni organizaciji in potem to znanje uporabili pri korespondenci, pisanju poročil in drugih podobnih nalogah.

4. Oglejmo si zdaj to, kar imenujemo politično učenje. To je učenje, ki je povezano $z$ odgovornim sodelovanjem in z zasedanjem odgovornih mest $\mathrm{v}$ imenu prostovoljnih organizacij. Sem sodijo tako preproste naloge kot naloge članov, izvoljenih v odbore. Ti so lahko tajniki, blagajniki, računovodje ali predsedniki prostovoljne organizacije. Skorajda četrtina članov prostovoljne organizacije od časa do časa prevzame odgovornost za opravljanje tovrstnih nalog. Če teče vse normalno, se le redki lahko izognejo takšnim nalogam, zato je razumljivo, da je večina vprašanih $\mathrm{v}$ naši študiji odgovorila, da so se v prostovoljni organizaciji naučili pomena in spretnosti, ki so osnova dejavnega državljanstva: sodelovanje v diskusiji, strpnost, sodelovanje, priprava politike organizacije, delo $\mathrm{z}$ drugimi in vo- denje drugih, usmerjanje dogodkov in pogosto tudi vodenje ljudi. Še več, mnogi so nasledke takšnega učenja prenesli na delovanje zunaj prostovoljne organizacije. Začeli so se zanimati za lokalno skupnost, nacionalna in mednarodna politična vprašanja in 25 odstotkov vprašanih je začelo dejavno sodelovati $\mathrm{v}$ političnem življenju. $\mathrm{V}$ naših študijah lokalne skupnosti smo odkrili, da je velik odstotek voljenih svetnikov v lokalni vladi začel politično delovati prav v prostovoljnih organizacijah.

5. Peta zvrst učenja je osebno učenje. To je učenje, ki ga je čutiti v trajni osebnostni spremembi posameznikov. Tisto, ki je ljudem pomagalo, da so se odkrili in razvili svoje zmožnosti. To je nedvomno najpomembnejša oblika učenja, kar jih lahko izkusimo. Takšno učenje lahko vznikne $\mathrm{v}$ kakršnem koli kontekstu, tako formalnem kot neformalnem.

Vendar smo tudi tokrat, tako kot $\mathrm{v}$ večini individualnih in skupinskih študij, ki smo jih opravili, ugotovili, da so se vprašani le redko in zelo nejasno zavedali svojega učenja in osebnostnih sprememb, ki so jih doživeli. Večina jih je le slutila. Potreben jim je bil strpen in potrpežljiv poslušalec, ki jih je utrdil v prepričanju, da je njihova izkušnja pomembna. Šele potem so se poglobili vase in tudi zavestno priznali pridobljene izkušnje. Kadar koli smo te izkušnje ozavestili, so vprašani začeli gledati nanje z začudenjem in radostjo. Potem so ugotovili, da bi lahko pridobljene izkušnje oblikovali in jih uporabili za nadaljnji napredek, za obvladovanje učenja in izkušenj. Odkrili smo, da so naše organizacijske študije prostovoljnih organizacij privedle do enakih spoznanj. Tudi prostovoljne organizacije same so menile, da jim konstruktivna vprašanja in pozorno poslušanje pomagajo do večjega organizacijskega vedenja in razvoja.

\section{KAKO JE VSE TO POVEZANO Z IZOBRAŽEVANJEM ODRASLIH}

Vprašali boste, kako se vse to povezuje $\mathrm{z}$ izobraževanjem odraslih. Videli smo, da se učenje in posledično osebnostno spreminjanje dogajata dokaj nezavedno, ker ljudje pač živijo in se morajo vsak dan spoprijeti z vsako- 


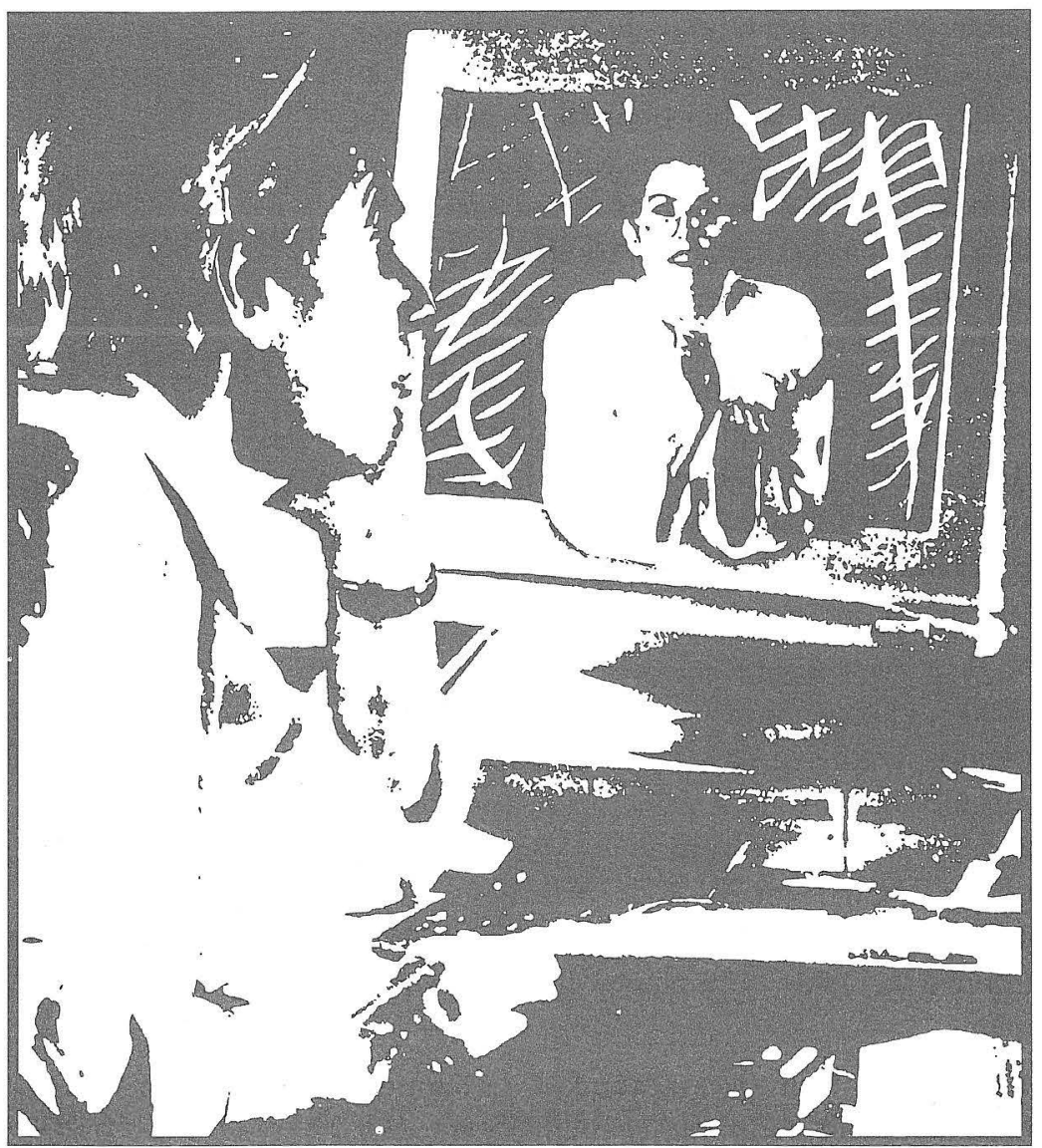

dnevnimi nalogami. Takšno učenje in spreminjanje postaneta močnejša in globlja, kadar gre za skupinsko izkušnjo sodelovanja v prostovoljni organizaciji.

Na začetku gre za bolj ali manj nezavedno pridobivanje spretnosti in informacij. Gre za učenje, podobno tistemu, ki ga doživimo ob mentorju, ko nas prosi, naj ga opazujemo in posnemamo. Takšno učenje, kot ga doživimo ob učiteljici šivanja, ki nas povabi, naj jo opazujemo, kako kroji, itd. Ali pa ob profesorju književnosti, ki predava o strukturi in lepoti pesmi, kar študente navda $\mathrm{z}$ občudovanjem, pa vendar ne poveča njihove modrosti.

Nekje na sredi je nogometni trener, ki razlaga taktiko igre, zakaj in kako meriti v cilj, kako to izkoristiti in kako uskladiti gibanje članov ekipe. Njegovi igralci se tako naučijo razumeti in ponotranjiti njegovo izkušnjo in jo uporabiti. Učiteljica šivanja razloži, zakaj in od kod njene metode krojenja. Naredi prikaz z ovojnim papirjem, pokaže sešita oblačila in nato stoji ob učencih in jim pomaga, da ne pride do napak, medtem ko ta ali oni opravlja nalogo in drugi gledajo, kako to počne. Profesor književnosti razloži, kako se lotiti kritične analize besedila, to pokaže in pripravi študente, da se tega lotijo na primeru drugega besedila ali pesmi.

Če imamo srečo, pa lahko izkusimo še drugačno učenje. Spominjam se velikega učitelja, ki je zelo uspešno zastavil scenarij prikaza, se lotil prav tistih vprašanj, ki so nas žulila, in se tako podal v samo bistvo besedila, potem pa nas je poslušal, ustvarjalno in potrpežljivo, vse dokler nismo sami poskusili odgovoriti na vprašanja. Po tistem smo odkrili, da o delu pišemo in govorimo bolj smiselno, kot smo sploh verjeli, da znamo. Pomagal nam je pridobiti spretnosti ustvarjanja in odkrivanja znanja o nas samih, potem pa je naše odkrivanje potrdil tako, da smo $\mathrm{v}$ tem procesu rasli, vsakokrat, ko smo bili izpostavljeni naslednjemu večjemu izzivu. Videl sem učiteljice šivanja, ki so ravnale podobno, ko so pripravile učence, da so začeli prek lastne postave in značaja odkrivati slog, barvo, blago in vzorce, ki jim ustrezajo. Pomagala jim je sodelovati $v$ skupini, pregledati probleme in izbrati rešitve $v$ praksi. Zatem so učenci ob živih ljudeh samostojno prišli do posplošitev glede uporabe načel in prakse.

Vse te primere smo opisali, da bi ponazorili eno izmed kategorij učenja in spreminjanja odraslih, ki smo jih navedli v zvezi s prostovoljnimi organizacijami - vsebinsko učenje. To se zdi razumno, kajti prostovoljne organizacije omogočajo več vsebinskega učenja odraslih kot velika večina izobraževalnih institucij, preprosto zato, ker so ples, petje, slikanje, šport, igra, zagovorništvo, skrb za ljudi itd. tudi njihov organizacijski cilj in vzrok, zaradi katerega se jim posamezniki pridružijo. Če se priključite organizaciji, ki redi golobe pismonoše, boste to storili zato, da se vključite $\mathrm{v}$ tekmovanja in da vzredite zmagovalce. To pomeni, da se morate naučiti marsičesa o anatomiji, genetiki, prehrani, meteorologiji, geografiji in obvladovanju stroškov in to znanje zmeraj znova dopolnjevati. Zdi se umestno, da si zdaj zastavimo dve vprašanji: (1) ali ima izobraževanje odraslih korist od ogromne zaloge izkušenj in znanja prostovoljnih organizacij; (2) ali imajo člani prostovoljnih organizacij korist od uporabe znanja iz izobraževanja odraslih in učnih metod?

Enako velja za organizacije in učenje v njih ter njihov razvoj. V njih se nabirajo ne le tradicija, temveč tudi izkušnje in savoir-faire. In 
Ne glede na to, katere vsebine poučujemo, moramo odrasle poučevati na način, ki ljudem omogoča, da ohranijo dostojanstvo. Moramo jim dati možnost, da postanejo tako dobri kot učitelj, omogočiti jim moramo, da gredo še dlje od učitelja. Kar najbolje morajo izrabiti svoje razvojne možnosti in postati neodvisni učenci, ki lahko sprejmejo nove izzive in se ne bojijo sprememb.

vendar so te organizacije pogosto slabo organizirane. Odnosi med prostovoljci in plačano delovno silo v takšnih organizacijah so kot jara kača. Veliko je nezgod, zavržene energije in truda. Temu bi se bilo največkrat mogoče izogniti, če bi pritegnili k sodelovanju ljudi, ki bi se strokovno spoznali na učenje. Člani sicer imajo izkušnje, vendar jih ne znajo uporabljati in prenašati na druge.

Vzemimo vprašanje vodenja, kontinuitete in spreminjanja, ki je bistveno za zdravje katere koli prostovoljne organizacije, ki noče zastati $\mathrm{v}$ razvoju. Vemo, da so potenciali vodenja $\mathrm{v}$ sleherni družbi dosti večji, kot se izkažejo v praksi. In vendar imajo prostovoljne organizacije velike težave, ko je treba najti naslednika predsednika, ki gre v pokoj, računovodje ali celo članov. Kljub temu se še zmeraj ne odpovedo vedno enakemu načinu pridobivanja članov. Na letni skupščini gre naokrog prošnja, naj se kdo prostovoljno prijavi. Nihče noče, ker so vsi preskromni ali pa se bojijo, da jih ne bi izbrali. Če pa si organizacije nenehno prizadevajo za pomoč pri nalogah in iščejo obetavne ljudi, ki imajo znanja in spretnosti, se bo okrepilo tudi zaupanje $\mathrm{v}$ takšne ljudi; ko jim bodo predlagali, da jih izvolijo, se ne bodo upirali in kontinuiteta organizacije bo omogočena.

\section{SKLEPNA RAZMIŠLJANIA}

$\mathrm{V}$ prostovoljnem sektorju se odvijajo različne vrste izobraževanja odraslih. Nekaj tega morda ni zelo kakovostno in tu bi prišla prav znanja, vedenja in spretnosti formalnega izobraževanja odraslih, medtem ko bi nekateri dobro razviti vidiki izobraževanja v prostovoljnih organizacijah lahko obogatili formalno izobraževanje. Institucionalno izobraževanje odraslih in prostovoljne organizacije se lahko dosti naučijo drug od drugega. Zveza izobraževalnih centrov (glej Allaway in Elsdon, 1962) si je dolgo prizadevala za povezavo neodvisnosti in odgovornosti prostovoljnih organizacij s tradicionalno močnim formalnim izobraževanjem odraslih. Kjerkoli živimo, pripadamo različnim okoljem, pogosto tudi mnogim prostovoljnim organizacijam. Ob tem igramo različne vloge. Prostovoljne organizacije vplivajo na kakovost življenja ter na skupnostne in politične spretnosti civilne družbe. Če posamezna skupnost potrebuje zdravo, demokratično civilno družbo, $v$ ta namen potrebuje tudi spodbude in izobraževanje prostovoljnega sektorja, prostovoljni sektor sam pa tudi potrebuje pomoč, da takšne spodbude in takšno izobraževanje odraslih uresniči.

\section{LITERATURA IN VIRI}

Allaway, A.J.: The Educational Centres Movement, 2nd edition, Leicester, NiaE, 1977.

Natten, T. R.: Communities and their Developement, London, =UP, 1957.

Brookfield, S.: Adult Learners, Adult Education and the Community, Milton Keynes, the Open University Press, 1983.

Clarke, R.: Enterprising Neigboughrs, London, NFCO and Community Projects Foundation, London, 1990.

Elsdon, K.T.: Centres for Adult Education, NIAE, London, 1962.

Elsdon, K.T.: Adult Learning in Volountary Organisations, Learning and Democracy, vol. 1. Case Studies 1 and 2, Continuing Education Press, Nottingham, 1991.

Percy, K.: Learning in Volountary Organisations, UDACE, Leicester, 1988 Stewart, S with Reynolds and Elsdon, Adult Learning in Volountary Organisations, Vol. 2. Case Studies 3-15, Continuing Education Press, Nottingham, 1992. 